Ostatni referat $w$ drugim dniu obrad przedstawił prof. T. Jałmużna (Uniwersytet Łódzki). Wystapienie dotyczyło aktualnych tendencji w badaniach nad szkolnictwem niepublicznym w Polsce.

Następnie wywiazała się dyskusja poświęcona problemom i kontrowersjom wokół szkolnictwa niepublicznego i państwowego w Polsce.

Podsumowania konferencji dokonał prof. T. Jałmużna. Uznał on konferencję za udana. Podkreślił, że toczace się dyskusje upłynęły w sprzyjającej naukowym rozmyślaniom atmosferze a trwałym rezultatem konferencji będzie $\mathrm{z}$ pewnościa odpowiednia publikacja pokonferencyjna.

Matgorzata Postuszna

\title{
Konferencja „W kręgu edukacji, nauki o niej i społeczeństwa”, 18 listopada 2002
}

W stolicy Wielkopolski, w Poznańskiej Alma Mater, 18 listopada 2002 roku, miało miejsce ważne wydarzenie-konferencja pt. „W kręgu edukacji, nauki o niej i społeczeństwa”, której szczególny charakter został nakreślony przez wieloaspektowe obszary pracy naukowej prof. zw. dra hab. Kazimierza Denka.

Celem ogólnopolskiego spotkania było określenie miejsca zajmowanego przez edukację i nauki zajmujace się nia.

Obrady podzielone zostały na dwie części. Specyfika pierwszej związana była z obchodami 70-lecia urodzin i 45-lecia pracy naukowej prof. Kazimierza Denka. Uroczystość prowadził prof. Eugeniusz Piotrowski. Po wysłuchaniu Gaude Mater Polonia w wykonaniu Chóru Kameralnego Collegium Posnaniensae pod dyrekcja prof. Barbary Nowak, JM Rektor UAM prof. Stanisław Lorenc uznajac Jubileusz prof. K. Denka za święto nadzwyczajne Uniwersytetu, zainaugurował konferencję. JM podziękował Jubilatowi za to, czym ubogacał przez wiele lat współpracowników, przyjaciół, studentów, m. in. za stworzenie fundamentów szkoły naukowej oraz za znaczny wpływ na obecny i przyszły kształt UAM.

Specjalnie dla Jubilata wystapił Zespół Kameralny Akademii Muzycznej, który zaprezentował utwór Mozarta.

Laudacje pt. „Życie twórcze zaangażowane, nastawione na zmianę i edukacyjny dialog” wygłosił prof. Janusz Gnitecki. Zwrócił szczególną uwagę na umiejętność łączenia przez Jubilata funkcji teoretyka i transformatywnego praktyka edukacji szkolnej. Przypominając najważniejsze etapy życia prof. K. Denka, porównał jego losy do egzystencji legendarnego Króla Ducha. Ponadto prelegent scharakteryzował zakresy pracy badawczej Jubilata. Najważniejszy z nich dotyczy edukacji w szkole, której prof. K. Denek poświęcił zarówno metodyczne, jak i teoretyczne teksty, dotyczące również znaczenia turystyki i krajoznawstwa w procesie wychowawczym i dydaktycznym. Pozostałe obszary pracy naukowej obejmuja $\mathrm{m}$. in. zagadnienia zwiazane $\mathrm{z}$ : dydaktyka ogólna i teoria ksztalcenia (cele, środki, metody, pomiar), reforma szkolnictwa (strategia reformy, pozycja szkoły w przemianach ustrojowych), wartościami i celami edukacji szkolnej, kształceniem i dokształcaniem zawodowym nauczycieli, metodologia badań pedagogicznych, przemianami i watkami edukacyjnymi w Polsce i na świecie. Prof. J. Gnitecki charakteryzujac dorobek naukowy prof. K. Denka, zwrócił również uwagę na jego najnowsze pozycje książkowe: „Aksjologiczne aspekty edukacji szkolnej”, „W kręgu edukacji, krajoznawstwa i turystyki w szkole”, „Poza ławka szkolna”.

Po krótkiej przerwie wyrazy sympatii oraz życzenia przekazali Jubilatowi goście, m. in.: prof. T. Lewowicki (Komitet Nauk Pedagogicznych), prof. S. Juszczyk, prof. W. Koiss (Uniwersytet Ślaski), prof. T. Kostrzyc (Akademia Wychowania Fizycznego - Wrocław), prof. W. Furmanek (Uniwersytet 
Rzeszowski), prof. J. Kuźma (Akademia Pedagogiczna - Kraków), prof. Z. Wiatrowski, mgr A. Gordon (PTTK), prof. A. Karpińska i prof. J. Niemiec (Uniwersytet Białostocki), prof. S. Kaczor, prof. F. Bereźnicki, prof. I. Kuźniak (UAM), prof. P. Kuleczka (Uniwersytet Zielonogórski).

Na zakończenie prof. K. Denek podsumował swoja dotychczasową działalność naukowa w aspekcie przestrzeni stricte intelektualnej oraz turystycznej.

Druga część konferencji przebiegala w dwóch sekcjach.

Sekcja pierwsza pod tytułem „Proces kształcenia i jego uwarunkowania” obradowala pod przewodnictwem prof. Franciszka Bereźnickiego oraz prof. Anny Karpińskiej. Prof. A. Karpińska, otwierając pracę w tej sekcji, zwróciła się do Jubilata prof. K. Denka, wyrażając szacunek i podziw dla pracy naukowej Profesora.

Obrady w sekcji rozpoczęło wystapienie prof. Krystyny Duraj-Nowakowej, która w referacie pt. „Edukacyjne wyzwania globalizacji" ukazała proces globalizacji w kategoriach zjawiska ekspansywnego, ale opanowanego dla edukacji.

Prof. Janina Wyczesany w wystapieniu pt. „Cechy osobowościowe pedagoga w opinii uczniów i nauczycieli” podkreśliła, iż w pracy pedagogicznej powinien istnieć „prymat serca nad prymatem rozumu".

Prof. Krystyna Zatoń poruszyła temat "Aplikacyjna wartość metod stosowanych podczas nauczania - uczenia się czynności motorycznych". Podkreśliła, iż najważniejsza umiejętnością nauczyciela jest stawianie celów kształcenia oraz metod nauczania, co w praktyce nie zawsze jest realizowane. Zdaniem referentki nauczyciele nie potrafią dokładnie precyzować celów i metod nauczania, w związku z tym skuteczność dydaktyczna jest bardzo niewielka.

Prof. Anna Karpińska w referacie swym pt. „W kręgu powodzeń i niepowodzeń edukacyjnych" zwrócila uwage na wybrane kręgi powodzeń, a zwłaszcza niepowodzeń szkolnych. Wyodrębnila ona siedem takich kręgów: 1 - niektóre konsekwencje cywilizacji edukacyjnej, 2 - konsekwencje modernizacji dla edukacji, 3 - nauczyciel, 4 - walka $z$ widmem przeciętności, 5 - próba spojrzenia na niepowodzenia z perspektywy rynku, 6 - nawiazanie do nauki poza ławka szkolna, 7 - dążenie ku lepszej szkole.

W kolejnych wystapieniach poruszano tematy dotyczące edukacji w ujęciu patriotycznym, rozpatrywano problem braku dostępności szkól dla dzieci wiejskich zamieszkujących Bory Tucholskie. Zastanawiano się nad rozwojem edukacji w ujęciu medialnym, nad uwarunkowaniami osobowościowymi i motywacyjnymi ucznia w procesie uczenia się.

Praca w sekcji drugiej odbywała się w dwóch grupach.

Grupa A, której przewodniczyli prof. Stanisław Palka oraz prof. Wanda Woronowicz, obradowała pod hasłem: „Aksjologiczne i teleologiczne problemy edukacji”. Poruszane tutaj tematy dotyczyły problemów wartości w kontekście współczesnej pedagogiki.

Obrady grupy B odbywały się pod hasłem: „Pedagogiczne aspekty krajoznawstwa i turystyki w szkole”. Przewodniczyli im prof. Zenon Jasiński oraz prof. Pola Kuleczka. Wiodacym aspektem dyskusji była szeroko rozumiana turystyka oraz jej ogromny wkład w wychowanie i kształcenie młodego pokolenia.

Organizatorzy konferencji zapowiedzieli druk referatów w materiałach pokonferencyjnych.

Justyna Gulczyníska, Katarzyna Kabacińska 